\title{
Assessment of river hydromorphological quality for restoration purposes: an example of the application of RHQ method to a Polish Carpathian river
}

\author{
Hanna Hajdukiewicz ${ }^{1}$ - Bartłomiej Wyżga ${ }^{1}$ Joanna Zawiejska ${ }^{2} \cdot$ Antoni Amirowicz $^{1}$. \\ Paweł Oglęcki ${ }^{3}$ Artur Radecki-Pawlik ${ }^{4,5}$
}

Received: 4 January 2017/ Accepted: 28 April 2017/Published online: 9 May 2017

(c) The Author(s) 2017. This article is an open access publication

\begin{abstract}
Planning and implementation of effective restoration projects require appropriate assessment of a river's hydromorphological status. Two European standards on hydromorphological assessment of rivers and hydromorphological assessment methods used in Poland are reviewed in the context of their applicability for river restoration purposes. River Hydromorphological Quality assessment method is presented with a case study of the Biała River, Polish Carpathians, where this assessment was
\end{abstract}

Bartłomiej Wyżga

wyzga@iop.krakow.pl

Hanna Hajdukiewicz

hanahaj@gmail.com

Joanna Zawiejska

zawiejsk@up.krakow.pl

Antoni Amirowicz

amirowicz@iop.krakow.pl

Paweł Oglęcki

oglecki@poczta.onet.pl

Artur Radecki-Pawlik

rmradeck@cyf-kr.edu.pl

1 Institute of Nature Conservation, Polish Academy of Sciences, al. Mickiewicza 33, 31-120 Kraków, Poland

2 Institute of Geography, Pedagogical University of Cracow, ul. Podchorążych 2, 30-084 Kraków, Poland

3 Department of Environmental Engineering, Warsaw University of Life Sciences, ul. Nowoursynowska 159, 02-787 Warsaw, Poland

4 Department of Hydraulics Engineering and Geotechnique, University of Agriculture, al. Mickiewicza 24/28, 30-059 Kraków, Poland

5 Faculty of Civil Engineering, Cracow University of Technology, ul. Warszawska 24, 31-155 Kraków, Poland used as basis for a restoration project aimed to establish an erodible river corridor. The results of the assessment revealed significant differences in hydromorphological quality between unmanaged and channelized river crosssections, indicating channel regulation as a major cause of the hydromorphological degradation of the Biała and confirming the choice of the erodible river corridor as an appropriate method of its restoration. The assessment indicated hydromorphological features of the river that were severely modified within the channelized reaches and which are likely to improve the most with the removal of bank protection and allowing free channel migration.

Keywords Hydromorphological quality .

Hydromorphological assessment - European standard .

River restoration - Erodible river corridor

\section{Introduction}

Human activity affects the state of riverine ecosystems through direct impacts on river biocoenoses (e.g. introduction of alien and invasive species), changes in water quality or physical state of habitats. Negative effects of deteriorated water quality on river ecosystems resulting from increased input of biogenic substances and pollution from sewage, agriculture or industry (Meybeck 2003) have been extensively described in the literature. Over the last decades, methods of assessment of the physicochemical water parameters were standardized (EPA 2001) and attempts to improve the quality of river water were commonly undertaken. Despite the widespread occurrence of practices leading to river change (e.g. channelization, gravel mining, disruption of river continuity by dams and flow regulation by dam reservoirs), their negative effects 
on the physical state of habitats and river biocoenoses were recognized relatively late (Muhar and Jungwirth 1998). In many countries, the necessity to improve the quality of river habitats only recently started to be noticed by water management authorities.

The term hydromorphology was introduced to describe physical river characteristics and processes as they determine the condition of river ecosystem. Hydrological regime, river continuity and morphological conditions were indicated in the Water Framework Directive as the three key elements of hydromorphological river quality (European Commission 2000).

According to the Water Framework Directive, the assessment of hydromorphological conditions supports the assessment of biological components of river ecosystems (European Commission 2000) which play a decisive role in the evaluation of river status. However, this assumption only reflects the feasibility of diagnosing the state of river biocoenosis rather than the conditioning factors. In reality, hydromorphological conditions are the primary control on the biotic elements of river ecosystems (Vaughan et al. 2009; Elosegi et al. 2010) as they influence the species richness of river communities (Elosegi et al. 2010) and many ecosystem functions such as nutrient and organic matter storage, rates of decomposition of organic matter, primary production and ecosystem respiration (Elosegi and Sabater 2013).

Proper functioning of river ecosystem requires its threedimensional connectivity: undisturbed migration of biota and sediment transfer along the river, at least seasonal connectivity between river water and water bodies in the floodplain area, and vertical connectivity between river and hyphorheic zone (Kondolf et al. 2006). Furthermore, the key controls on river hydromorphological quality are the spatial complexity of habitats and dynamism of hydrological and morphological processes (Elosegi et al. 2010). Even with the lack of human intervention in river channels and floodplains, hydromorphological conditions are not static but undergo constant changes as the rivers adjust to changing environmental conditions in the catchments and valley floors (Dufour and Piégay 2009). This creates the need to determine the dynamically changing reference conditions that relate to the contemporary environmental conditions in the catchments (Wyżga et al. 2012b).

With the degradation of river ecosystems, in several countries actions were undertaken to improve their state or re-establish natural features of river hydromorphology (Habersack and Piégay 2008; Rinaldi et al. 2013c). In Europe, restoration efforts were supported by the regulations of the Water Framework Directive that obliged the member states to re-establish good ecological status of rivers by 2015 (European Commission 2000). Consequently, a number of assessment methods were developed in particular countries to enable systematic evaluation of river hydromorphological quality (Rinaldi et al. 2013a). Attempts at the standardization of these procedures brought about reviews (Belletti et al. 2015) and comparisons of the methods used in different countries (Raven et al. 2002; Scheifhacken et al. 2012), and the European Committee for Standardization published two standards with the nomenclature and framework for hydromorphological evaluation of rivers (Boon et al. 2010). However, many of the applied methods have one or more limitations: (1) they had been developed before the introduction of the Water Framework Directive and even though they provided the basis for its hydromorphological guidelines, they are not fully adjusted to its regulations; (2) they consist in static inventory of river habitat features and as such do not allow recognition of the ongoing hydrological and geomorphological processes; (3) they are general and involve little or no field surveys. As a consequence of the two latter limitations, these methods of assessment are of very limited use for the purposes of river restoration. The adequate assessment method should be based on detailed recognition of the extent and causes of degradation of river's hydromorphological conditions and allow the analysis of this state not only in the context of past human intervention in the river channel and corridor but also in the context of river adjustment to environmental changes (Wyżga et al. 2012b; Rinaldi et al. 2013b).

In Poland, significant degradation of many rivers calls for restoration measures that would allow improvement of river integrity. Hydromorphological evaluation of rivers in the country has been performed with a few methods (Lewandowski 2012). The lack of a versatile, suitable method of assessment led to the development of River Hydromorphological Quality (RHQ) method (Wyżga et al. 2009, 2010b) designed also for the purpose of planning and evaluation of restoration measures.

This paper aims to provide:

- a critical review of European standards on the assessment of river hydromorphology;

- an overview of the methods of river quality assessment most widely used in Poland;

- a presentation of the RHQ method and its use with a case study of the Biała River as well as the discussion of applicability of this method for river restoration purposes.

\section{European standards of hydromorphological assessment}

Studies focused on developing methods of hydromorphological assessment of rivers started in European countries long before the introduction of the Water Framework 
Directive; and in Poland in the early 1990s (Lewandowski 2012). The directive created the need for unification of the methods of hydromorphological assessment of rivers, resulting in the publication of two guidance standards by the European Committee for Standardization (Boon et al. 2010). European Standard EN 14614 (CEN 2004) indicated guidelines for hydromorphological assessment of river features. It indicated 10 assessment categories, six of which related to the assessment of channel, two to banks and riparian zone, and two to floodplain/river corridor (Table 1). For particular categories, the standard identified hydromorphological features that should be assessed (Table 1).

European Standard EN 15843 (CEN 2010) provided guidelines to the assessment of anthropogenic modifications of river hydromorphology. Among the assessment categories listed in EN 14614 standard, those crucial for the evaluation of anthropogenic modification to river hydromorphology (so-called core categories) were now distinguished from the remaining group of subsidiary

Table 1 Assessment categories and features of the channel, banks, riparian zone and floodplain of the Biała assessed to evaluate the hydromorphological quality of the river according to the European categories of features that may exert a positive influence on the quality of river habitats (Table 1). The standard asserts that categories from the first group do not require definition of reference conditions and the degree of modification in each category is considered proportional to the share of the modified part of assessed reach in its total length. Only the evaluation of the second group of categories requires comparison of the observed river state to the reference conditions defined for the relevant river type.

This second European standard contains both valuable elements and ones that make this methodology of hydromorphological river assessment of little or no use for river restoration purposes. Undoubtedly, the advantage of the standard is that it uses a degree of deviation from natural conditions, and not the abundance of morphological conditions considered beneficial for river biota, to assess river hydromorphological quality (Boon et al. 2010).

The method of assessment presented in the standard is largely simplified; this can be advantageous if rapid evaluation of numerous rivers is to be performed to comply

Standard EN 14614 (CEN 2004) and classification of assessment features as core or subsidiary in the European Standard EN 15843 (CEN 2010)

\begin{tabular}{|c|c|c|c|}
\hline No. & Assessment category & Assessed feature & $\begin{array}{l}\text { Core/subsidiary } \\
\text { feature }\end{array}$ \\
\hline \multicolumn{4}{|c|}{ Channel } \\
\hline \multirow[t]{2}{*}{1} & \multirow[t]{2}{*}{ Channel geometry } & Channel planform & Core \\
\hline & & Channel cross-section and longitudinal profile & Core \\
\hline \multirow[t]{2}{*}{2} & \multirow[t]{2}{*}{ Substrate } & Artificial/natural bed substrate & Core \\
\hline & & Degree of modification of substrate material & Subsidiary \\
\hline \multirow[t]{2}{*}{3} & \multirow[t]{2}{*}{ In-river vegetation and organic debris } & Aquatic vegetation and island vegetation within the river's active zone ${ }^{a}$ & Subsidiary \\
\hline & & Organic material (leaves, woody debris) & Subsidiary \\
\hline 4 & Erosion/deposition features & Presence of erosional and depositional channel forms & Subsidiary \\
\hline \multirow[t]{3}{*}{5} & \multirow[t]{3}{*}{ Flow } & $\begin{array}{l}\text { Modification of natural flow hydraulics by engineering works and } \\
\text { structures }\end{array}$ & Core \\
\hline & & Modification of natural flow regime & Core \\
\hline & & Degree of connectivity between river channel and hyporheic zone ${ }^{a}$ & $\begin{array}{l}\text { Not considered in } \\
\text { EN } 15843\end{array}$ \\
\hline 6 & Longitudinal river continuity & $\begin{array}{l}\text { Impact of engineering structures on longitudinal river continuity- } \\
\text { sediment transport and biota migration }\end{array}$ & Core \\
\hline \multicolumn{4}{|c|}{ Banks and riparian zone } \\
\hline 7 & Bank structure & Modification of river banks (material, profile, height) & Core \\
\hline 8 & Riparian zone & Vegetation and land use in the riparian zone & Core \\
\hline \multicolumn{4}{|c|}{ Floodplain } \\
\hline \multirow[t]{2}{*}{9} & \multirow{2}{*}{$\begin{array}{l}\text { Land use and associated features in } \\
\text { the river corridor }\end{array}$} & Land use in the river corridor/floodplain & Core \\
\hline & & Presence of remnant channels, oxbows and mires within the floodplain & Core \\
\hline \multirow[t]{2}{*}{10} & \multirow[t]{2}{*}{$\begin{array}{l}\text { Lateral connectivity and channel } \\
\text { migration }\end{array}$} & $\begin{array}{l}\text { Degree of lateral connectivity of river and floodplain, and continuity of } \\
\text { floodplain along the river }\end{array}$ & Core \\
\hline & & Constraint on lateral channel movement & Core \\
\hline
\end{tabular}

\footnotetext{
${ }^{\text {a }}$ Feature modified or added to the list indicated in European Standard EN 14614
} 
with the requirements of the Water Framework Directive. However, it will be entirely unusable for river restoration that must be based on adequate and credible recognition of the degree and causes of degradation of the river in question. A serious flaw of this methodology is the lack of relating the state of the assessed river to relevant reference conditions and the assessment of several categories of features on the basis of the percentage of river length in which they have been modified, without considering the degree of the modification.

This opinion can be illustrated with the following example. Planform geometry of a wide river with multithread channel may be variously modified by human activity. In the most extreme case, channelization of the multi-thread channel will result in the formation of a significantly narrower, single-thread channel. Transformation of the channel planform can also consist in its partial constriction with groynes and a reduction in the number of low-flow channels, while the multi-thread channel pattern is maintained. If both such changes occur along a similar length of assessed river reaches, according to the EN 15843 methodology the degree of channel modification should be considered equal in either case. At the same time, it is evident that the degree of deviation from natural conditions for both cases is different. This example can be related to the Italian river Tagliamento which is considered a model ecosystem of an Alpine river with undisturbed, braided channel pattern (Tockner et al. 2003). Over the past century, the width and the braiding index of the Tagliamento decreased by half (Surian and Rinaldi 2004), partially as a result of the river adjustment to decreasing bedload supply and partially because of engineering works carried out along the entire reach length. According to the EN 15843 standard, the current channel planform should then be considered extremely modified, which contradicts the wide recognition of the state of this river as nearly natural. Similar paradoxical results are obtained when EN 15843 methodology is applied to assess other categories of river hydromorphological quality.

\section{Hydromorphological assessment methods and their utility for river restoration purposes}

\section{Attributes of assessment methodology useful for river restoration purposes}

To be applicable for the purposes of river restoration, a method of hydromorphological assessment must fulfill the following criteria:

- the assessment should aim to determine the degree of deviation from typical undisturbed conditions for a given river rather than the abundance of habitat features beneficial for river biota (CEN 2010) that may vary between different types of watercourses;

- degree of modification of river hydromorphology is determined in relation to reference conditions that define the best attainable river state under contemporary environmental conditions in the catchment (Wyżga et al. 2012b);

- the assessment is largely based on field surveys to allow adequate recognition of the type, location and extent of the modification to river hydromorphology;

- the methodology allows to recognize hydrological and geomorphological processes that control the state of the river ecosystem, including the processes of river adjustment to changing environmental conditions ( $\mathrm{Ri}-$ naldi et al. 2013b).

\section{Methods of hydromorphological assessment and their suitability for river restoration purposes}

Below we review the general groups of methods of hydromorphological assessment in the context of their applicability for the purposes of river restoration. Methods evaluating the quality of physical river habitats, such as the German LAWA-FS (LAWA 2000) or the British River Habitat Survey, RHS (Raven et al. 1997), are most common worldwide and have been in use the longest (Rinaldi et al. 2013a; Belletti et al. 2015). This category encompasses methods for the survey and characterization of physical habitat elements, which can be classified as river habitat surveys or physical habitat assessments (Belletti et al. 2015). Although these methods are based on field surveys, they do have certain limitations which put in question their applicability for hydromorphological assessment in river restoration projects. With the large number of parameters to be assessed, these methods are time-consuming but yield a static image of a river unrelated to ongoing geomorphological processes, especially the existence or lack of geomorphic dynamic equilibrium and the processes of river adjustment to changing environmental conditions (Rinaldi et al. 2013a, c). Of this group, the RHS is rather popular in Poland (Szoszkiewicz et al. 2007).

In Europe, several methods of hydromorphological assessment have been developed for the purposes of monitoring required by the regulations of the Water Framework Directive (Rinaldi et al. 2013a). Some of these methods are relatively new: e.g. HEM in the Czech Republic (Langhammer 2007) or Polish MHR (Ilnicki et al. 2010a). The main aim of these methods is to provide a fast assessment of many rivers to determine their hydromorphological state and report on it to the European 
Table 2 Comparison of hydromorphological assessment methods used in Poland and their applicability for river restoration

\begin{tabular}{|c|c|c|c|c|c|}
\hline Method & Reference conditions & $\begin{array}{l}\text { Criteria used in } \\
\text { hydromorphological evaluation }\end{array}$ & $\begin{array}{l}\text { Field data } \\
\text { collection }\end{array}$ & $\begin{array}{l}\text { Consideration } \\
\text { of physical } \\
\text { processes }\end{array}$ & $\begin{array}{l}\text { Applicability } \\
\text { for river } \\
\text { restoration }\end{array}$ \\
\hline $\begin{array}{l}\text { River habitat survey } \\
\text { (RHS) }\end{array}$ & $\begin{array}{l}\text { Combination of near-natural } \\
\text { habitat conditions with } \\
\text { habitat quality score within } \\
\text { the } 20 \% \text { highest ranked sites }\end{array}$ & $\begin{array}{l}\text { Degree of habitat modification } \\
\text { and habitat quality (based on } \\
\text { the diversity and richness of } \\
\text { habitat features beneficial for } \\
\text { river biota) }\end{array}$ & $\begin{array}{l}\text { All evaluated } \\
\text { features }\end{array}$ & Not included & Limited \\
\hline $\begin{array}{l}\text { Hydromorphological } \\
\text { monitoring of rivers } \\
\text { (MHR) }\end{array}$ & $\begin{array}{l}\text { River state in the mid-20th } \\
\text { century, prior to } \\
\text { intensification of agriculture }\end{array}$ & $\begin{array}{l}\text { Degree of deviation from } \\
\text { undisturbed (reference) } \\
\text { conditions }\end{array}$ & $\begin{array}{l}\text { Some features } \\
\text { surveyed } \\
\text { along } 10 \% \text { of } \\
\text { the length of } \\
\text { evaluated river }\end{array}$ & Not included & No \\
\hline $\begin{array}{l}\text { River } \\
\text { hydromorphological } \\
\text { quality (RHQ) }\end{array}$ & $\begin{array}{l}\text { Best attainable river state } \\
\text { under current environmental } \\
\text { conditions in the catchment } \\
\text { but without human impact } \\
\text { on the river }\end{array}$ & $\begin{array}{l}\text { Degree of deviation from } \\
\text { undisturbed (reference) } \\
\text { conditions }\end{array}$ & $\begin{array}{l}\text { All evaluated } \\
\text { features }\end{array}$ & Included & Yes \\
\hline
\end{tabular}

${ }^{a}$ Refers to the method sensitivity to identify features that would need to be restored and will probably be improved by restoration measures

Commission. Their general approach is thus in agreement with the expected outcomes. These methods are based on the analysis of maps, aerial photos and orthophotos as well as information in existing relevant databases, with very little data collected in field surveys, which severely limits the use of these methods for detailed planning and monitoring of restoration projects.

The third group of methods used in many countries is these based on field inventory of the river condition but in which evaluation is also based on the assessment of the ongoing processes, such as existence or lack of three-dimensional connectivity of river ecosystem, stability, erosion or accretion of river banks and channel adjustment to environmental conditions. These methods involve evaluation of the entire river corridor and both present and recent river change analysed on maps, aerial photos and orthophotos (Rinaldi et al. 2013a; Belletti et al. 2015). This group of methods includes, among others, the Australian River Styles Framework (Brierley and Fryirs 2005); IHG method in Spain (Ollero et al. 2011), MQI in Italy (Rinaldi et al. 2013b) and Polish method of river hydromorphological quality assessment RHQ (Wyżga et al. 2009, 2010b, 2012b). Consideration of ongoing processes and field recognition of the river state make these methods most suitable for river restoration purposes.

\section{Methods of hydromorphological assessment used in Poland}

Below we briefly describe principal methods of hydromorphological assessment used in Poland. River Habitat Survey method, developed in the UK, belongs to the methods assessing physical river habitat and is frequently used in Poland where its application is facilitated by a country-specific manual (Szoszkiewicz et al. 2007). This method does not account for ongoing geomorphological processes and some other deficiencies related to its use are specified below (Table 2). The method determines the degree of anthropogenic modification of the river habitat and its quality reflected in the presence and richness of the features considered beneficial for river biota (Raven et al. 1997). The set of hydromorphological parameters existing under undisturbed conditions may differ considerably between rivers in different physiographic settings $(\mathrm{Ku}-$ janová et al. 2016) and, thus, hydromorphological evaluation based on habitat quality index does not seem appropriate as in many rivers low richness or diversity of habitat features is natural and reflects naturally low morphological diversity of these rivers (Wyżga et al. 2012b). Although the users of the RHS method notice various degrees of diversity of particular river habitat features in different regions (Szoszkiewicz et al. 2006), they persist in using the index of habitat quality. The RHS method also uses habitat quality as one of the components in defining reference conditions for a particular river type. Highquality (reference) hydromorphological conditions are here associated with the sites in which the low degree of anthropogenic modification allows them to be classified as near-natural and the habitat quality score falls within the 20\% highest ranked sites (Raven et al. 2002).

The Polish MHR method was developed for the rapid assessment of rivers for the purposes of the Water Framework Directive. As a result, only few analysed parameters are determined in a field survey along $10 \%$ of 
the length of an assessed river (Ilnicki et al. 2010a). The method evaluates an almost full range of river features indicated in the EN 14614 standard (Ilnicki et al. 2010a); however, it also has a few serious flaws indicated below (Table 2). Descriptive/qualitative evaluation of some parameters prohibits their inclusion in the quantitative indices of hydromorphological quality. Bed substrate that cannot be assessed with use of cartographic data is excluded from evaluation. Reference conditions were defined as those existing in the mid-20th century, prior to the intensification of agriculture in the catchments (Ilnicki et al. 2010b). This manner of defining reference conditions is hardly acceptable; although cultivation may significantly impact river water quality, especially the content of biogenic substances, its influence on hydromorphology is negligible, particularly in comparison with channelization works. In mountain catchments, agricultural practices may increase the supply of fine sediment to the rivers, but in Europe, including Poland, the culmination of agricultural and pastoral pressure in mountain areas occurred in the 19th century and has since progressively decreased (Kondolf et al. 2002; Wyżga et al. 2012b). Finally, in the case of some parameters such as channel slope, width and depth or bank inclination, their higher variability is associated with a better state of the river (Ilnicki et al. 2010a). This resembles the manner of evaluation typical of RHS method, based on the diversity of habitat features rather than on the degree of deviation from the conditions that would be natural for a particular river (surface water body).

With a lack of relevant assessment procedure that would provide insight into both river state and active fluvial processes in Poland, a new method of assessment-River Hydromorphological Quality, RHQ, was developed (Wyżga et al. 2009, 2010b) to enable evaluation of hydromorphological river conditions in the context of its contemporary dynamics. This method is described in detail below.

\section{Hydromorphological assessment of river quality with RHQ method}

Hydromorphological evaluation can be carried out for parts of a river course with similar hydrology and morphology (surface water bodies), for segments of water bodies (survey units) or for river cross-sections (CEN 2004). Evaluation with RHQ method can also be performed for these spatial units of rivers. This paper presents evaluation of 20 cross-sections of the Biała River located in its upper and middle course that was performed with this method.

Hydromorphological assessment of the river in the analysed cross-sections involved scoring of 10 groups of features of the channel, banks and riparian zone as well as floodplain/river corridor (Table 1) specified in the European Standard EN 14614 (CEN 2004; Wyżga et al. 2010b). Two features were added to the ones listed in the European Standard EN 14614: river island vegetation and the degree of connectivity between river channel and hyporheic zone. As a result, assessment of aquatic vegetation was replaced with the assessment of both aquatic and terrestrial vegetation in the active zone of the river. This better reflected the role of island vegetation in the formation of the ecosystem of multi-thread rivers (Mikuś et al. 2013) and the differences in the naturalness of vegetation on islands and in the riparian zone of mountain rivers (Kaczka et al. 2008). In the evaluation of modifications to river flow, the assessment of runoff regime and flow hydraulics was supplemented with the assessment of the degree of connectivity between river channel and hyporheic zone. Unrestricted water exchange between river channel and the alluvium is important for river biota (Brunke and Gonser 1997), and its anthropogenic disturbances such as clogging of interstices in the gravel framework with fines (Wood and Armitage 1997) or significant channel incision and transformation of alluvial boundary conditions into bedrock ones (Rinaldi et al. 2013c) limit or prevent such exchange. This feature should be evaluated for almost all river types with the exception of watercourses that naturally flow in bedrock channels. By contrast, naturalness of river island vegetation can be evaluated only for island-braided (multithread), wandering and anastomosing rivers.

Hydromorphological assessment of the river is preceded by field inspection and the presentation and analysis of extensive data on the river to achieve congruent understanding of the evaluation procedure and river state. First, for each assessed hydromorphological feature, near-natural and extremely modified conditions are defined. Near-natural conditions correspond to the development of a given feature under reference conditions for the particular river, whereas similar extremely modified state (e.g. paved floodplain) may be relevant for a range of river types. For example, near-natural conditions in the floodplain area/ river corridor were described as a mosaic of various successional stages of vegetation, including tamarisk (Myricaria germanica) and willow shrubs and mature willow or alder forest (Fig. 1a). Extremely modified conditions were represented here by a parking area with impermeable surface and typified by very low hydrodynamic roughness (Fig. 1b). In turn, near-natural conditions of lateral connectivity and channel migration accompanied unprotected alluvial channel banks with the height typical of the vertically stable river (Fig. 2a). Extremely modified conditions were represented by the presence of bank reinforcement and significant channel incision, precluding lateral channel migration and inundation of riparian areas by floodwaters (Fig. 2b). With near-natural and extremely 

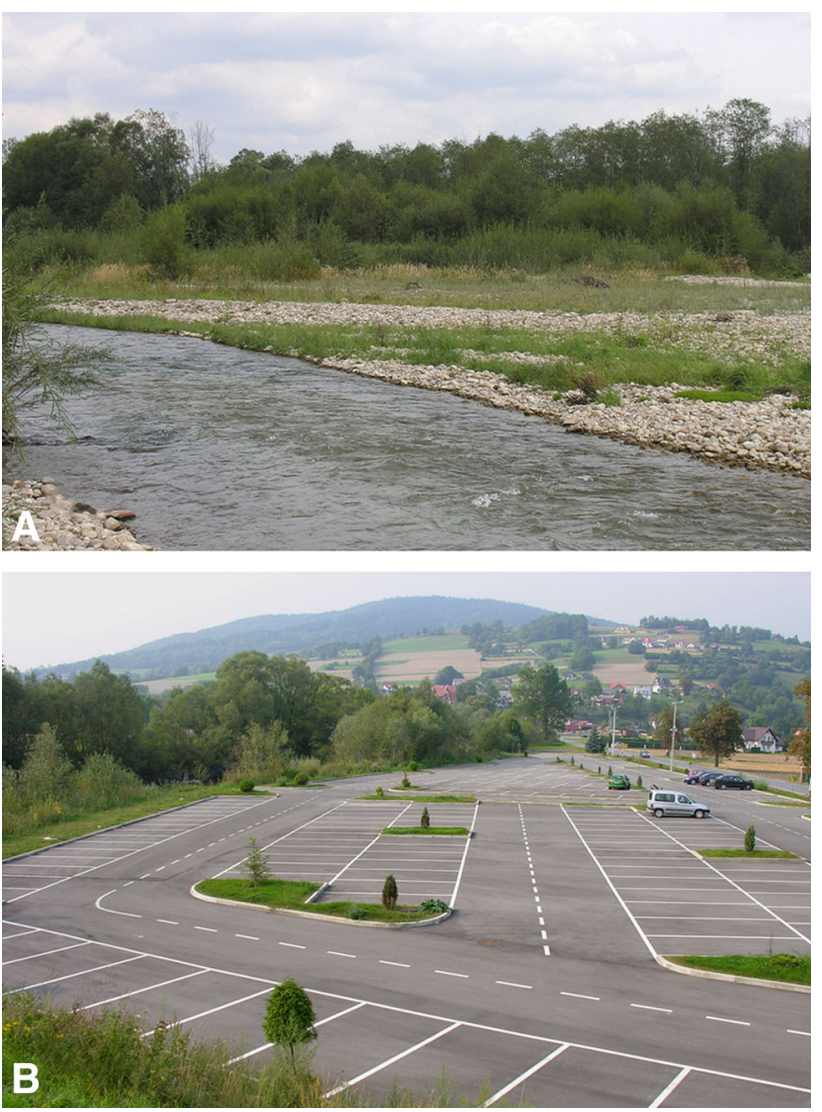

Fig. 1 Examples of near-natural (a) and extremely modified conditions (b) for land use in the river corridor. Under near-natural conditions, various successional stages of vegetation occur in the floodplain area, from tamarisk (Myricaria germanica) and willow shrubs to mature willow or alder forest. The asphalt-paved parking place adjacent to the river bank represents extremely modified conditions

modified states of a given feature identified, particular experts evaluate the spectrum of conditions between these extreme states in terms of their impact on the quality of the river ecosystem.

Second, hydromorphological reference conditions are indicated as those representing the best attainable river state. Significant environmental changes that occurred in the Polish Carpathian catchments during the 20th century, especially a decline in high-intensity farming and grazing and subsequent hillslope afforestation (Lach and Wyżga 2002; Kozak et al. 2007), preclude use of the historical state of the rivers, presented on 19th-century maps, as hydromorphological reference conditions (Wyżga et al. 2012b). Instead, the conditions should be defined as the river state that exists or would exist under contemporary environmental conditions in the catchment but with no human modifications to channel, riparian areas and floodplain of a river (Wyżga et al. 2012b).

Third, the current state of the river is characterized with diagrams of channel morphology in the assessed cross-
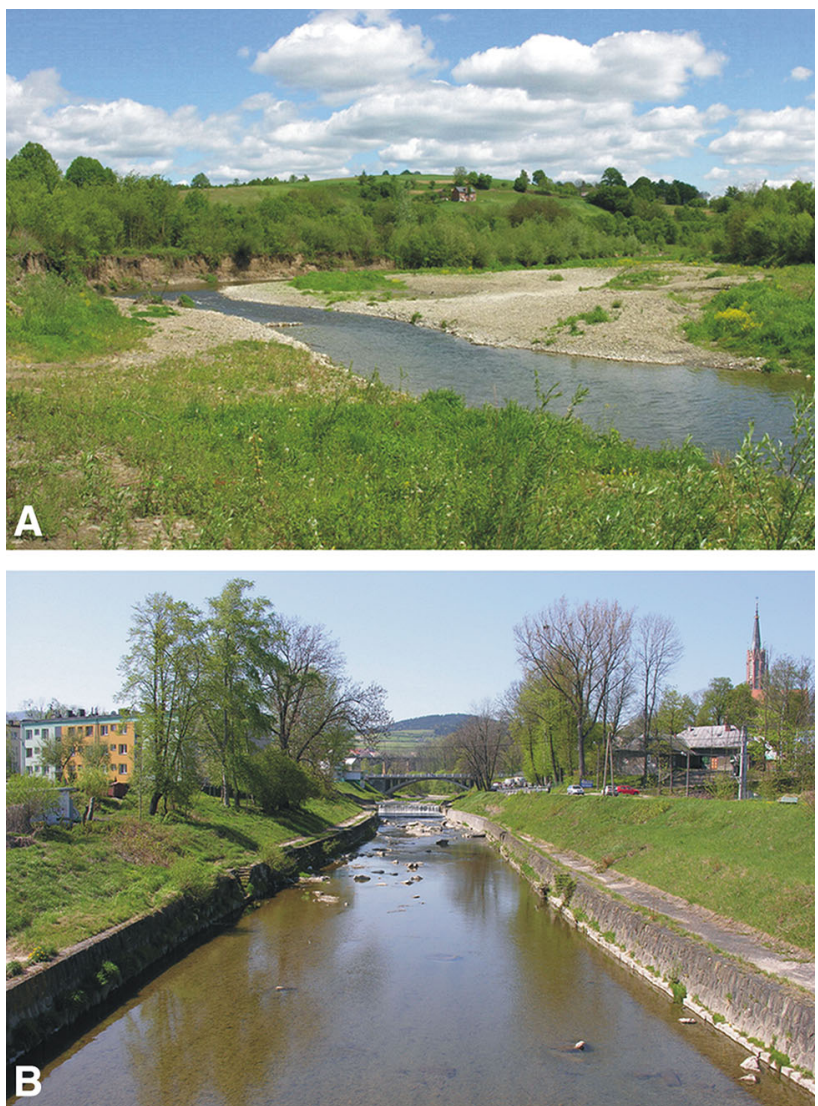

Fig. 2 Examples of near-natural (a) and extremely modified conditions (b) for lateral connectivity of the river ecosystem and channel migration. The unmanaged, sinuous channel can freely migrate on the floodplain. The mode of river channelization presented in the lower photo results not only in the lateral stability of the channel but also in the loss of lateral connectivity of the river ecosystem

sections, photographs of the cross-sections and position of the river on the orthophoto (Fig. 3). Finally, changes that occurred in the river sections adjacent to the assessed crosssections over the last few decades are presented using historical maps as well as archival aerial and ground photographs from the second half of the 20th century (Fig. 4). From this period, good cartographic and photographic documentation of river changes is available and it provides information on both human-induced modification of the river and trends in channel adjustment to changing environmental conditions (Wyżga et al. 2010b), especially important as some of these changes could have been very fast (Fig. 4). The analysed river sections should extend upstream and downstream of the evaluated cross-sections on the length of at least 2 channel widths from the beginning of the period considered; their absolute length is thus variable depending on the river size in a given valley reach and the degree of change in channel width over the last few decades.

Hydromorphological evaluation of the river was performed by five experts in fluvial geomorphology, river engineering and freshwater ecology. Each river feature 
Fig. 3 Examples of the sources of information used to evaluate hydromorphological quality of the Biała in the surveyed crosssections from the upper course of the river, shown for crosssection $2 A$ with single-thread, regulated channel and crosssection $2 B$ with multi-thread channel
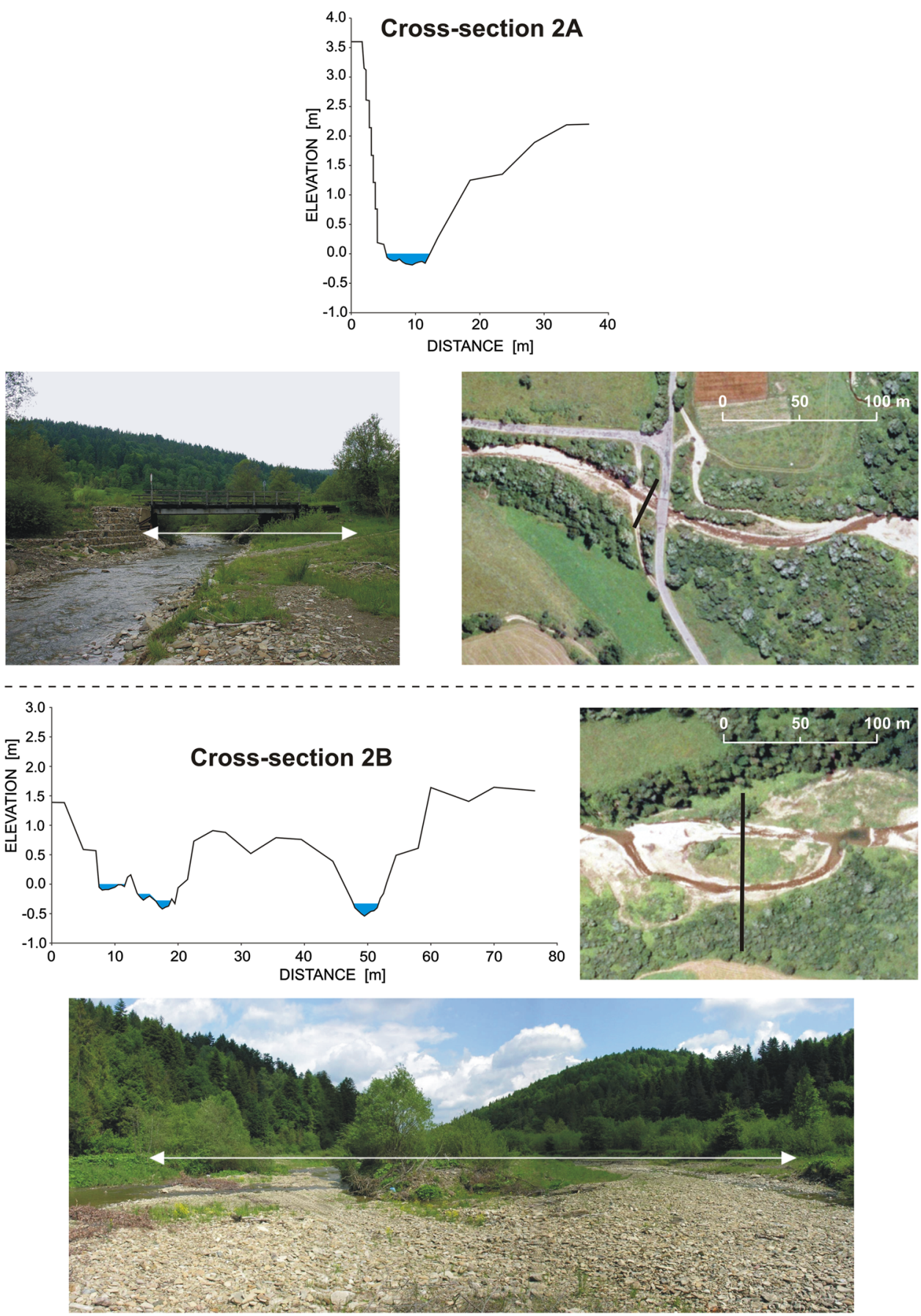

was scored on a scale from 1 (near-natural conditions) to 5 (extremely modified conditions). For categories consisting of two or three evaluated features (Table 1), the score was averaged. Final evaluation of the hydromorphological quality in a cross-section was expressed by the average of scores in the assessed categories, given by the five experts. Based on this final score, particular crosssections were associated with one of the five classes of hydromorphological quality (high, good, moderate, poor and bad).

\section{Hydromorphological assessment of the Biała river}

\section{Study area}

The Biała is a gravel-bed river draining a catchment with an area of $983 \mathrm{~km}^{2}$ in the Polish Carpathians (Fig. 5). The river rises at about $730 \mathrm{~m}$ a.s.l. and has relatively gentle channel slope that decreases from 0.017 to 0.003 on the length of the studied sections. With such channel slope, the river is typified by a riffle and pool channel pattern 

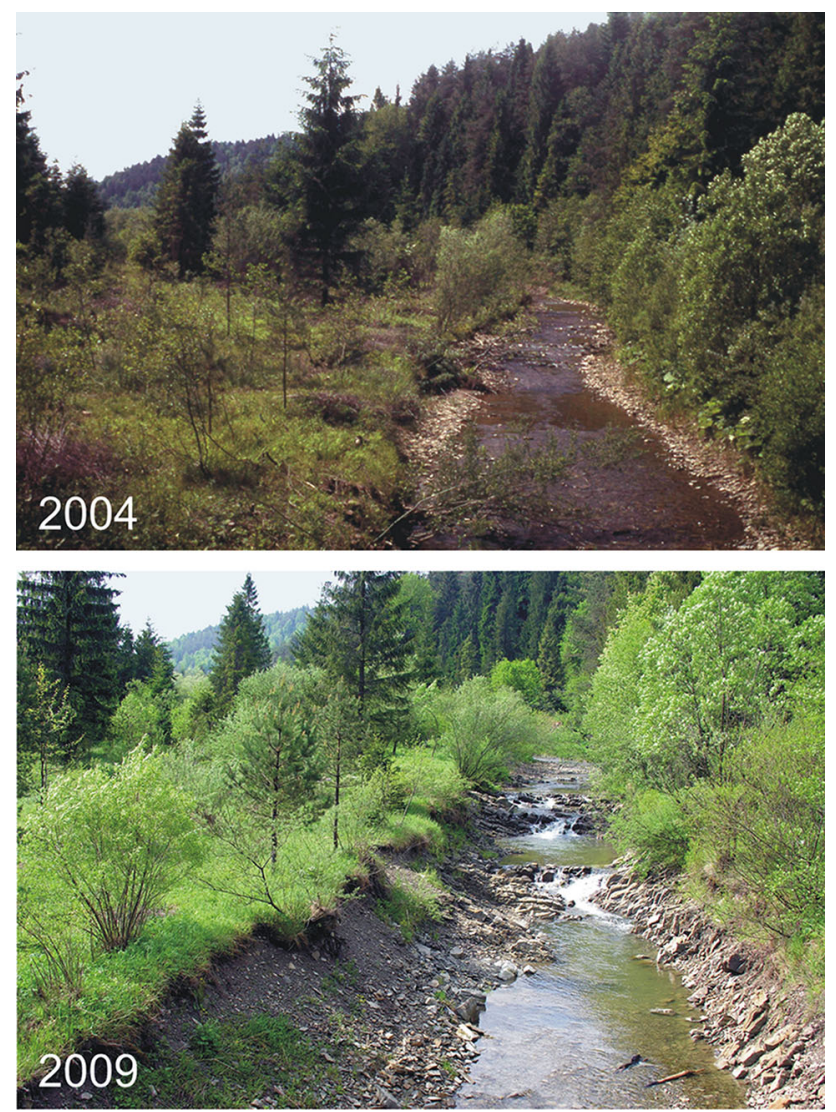

Fig. 4 Incision of the Biała River and transformation of its alluvial channel into a bedrock one that occurred between 2004 and 2009 in the vicinity of site 1 as a result of upstream-progressing bed degradation induced by the gravel exploitation carried out $1 \mathrm{~km}$ downstream. The photos are examples of the data used to present changes of the river having occurred over the few past decades in the vicinity of the evaluated cross-sections

according to the classification of Montgomery and Buffington (1997). In its upper course, the river flows through low mountains of Beskid Niski where it is supplied with coarse and medium-sized sandstone material. Very high flow variability in this part of the Biała and the delivery of coarse, non-cohesive sediment to the unmanaged river result in the formation of a wide, multi-thread channel (cf. Wyżga et al. 2016b). In the middle course within the Ciężkowice Foothills, the Biała flows across alternating sandstone and shale complexes that are the source of cobble to pebble material along with large volumes of fines. As a result, the Biała remains a gravel-bed river but under undisturbed conditions it forms a sinuous channel.

In the 20th century, the Biała was subjected to severe modification resulting from human activity. In the lower part of its upper course and along the entire middle course, channel width decreased significantly (to a quarter or a sixth of the initial value) and the river incised by as much as $2.5 \mathrm{~m}$. The principal cause of these changes was river channelization leading to the formation of a narrow and straight channel (cf. Wyżga 2001, 2008). These changes were strengthened by widespread, uncontrolled in-channel gravel mining (cf. Rinaldi et al. 2005). The tendency to channel narrowing and incision could have also been reinforced by a reduction in sediment supply to the river (cf. Lach and Wyżga 2002) resulting from a considerable increase in forest cover in the mountain part of the catchment after the World War II (Kozak et al. 2007). Some human impacts such as illegal in-channel gravel mining (Wyżga et al. 2010a) and the removal of large wood from the river have continued also in recent years.

Channel changes presented above are known to incur a range of negative effects, such as decreased storage of floodwater in floodplain areas and the resultant increase in peak flows of flood waves in downstream river reaches (Wyżga 1997; Kundzewicz et al. 2014; Wyżga et al. 2016a) or deterioration of the state of river biocoenosis (Wyżga et al. 2013). To limit the negative consequences of the channel changes and improve hydromorphological quality of the Biała, an erodible river corridor was established in the mountain and foothill river sections (14.5 and $5.9 \mathrm{~km}$ in length, respectively) (Fig. 5). Both parts of the corridor consist of alternating river reaches with a given type of channel management: longer (1-3 km) unmanaged reaches and shorter $(0.1-0.3 \mathrm{~km})$ channelized ones adjacent to bridges. Following establishment of the corridor, the river is allowed to develop its channel freely in the unmanaged reaches, whereas it remains channelized in the vicinity of bridges. Future improvement of hydromorphological state of the river, resulting from unrestricted formation of the Biała channel within the corridor, is thus expected to occur in the unmanaged reaches, whereas the state of the channelized reaches will most likely remain unchanged.

Prior to the start of the restoration project on the Biała, hydromorphological quality assessment was performed for 10 sites, with each site consisting of a pair of cross-sections located in neighbouring unmanaged and channelized river reaches. These pairs of cross-sections were selected to determine differences in hydromorphological quality of the river between its channelized and freely developing reaches at the beginning of the restoration project. Hydromorphological assessment will be repeated at the end of the project to demonstrate its effectiveness in improving the river status in the unmanaged reaches. The average distance between unmanaged and channelized cross-sections at the sites equals $780 \mathrm{~m}$ and is 22 times greater than the average channel width in the twenty studied crosssections. It is considered sufficiently large to ensure that fluvial processes in the unmanaged cross-sections are not influenced by hydraulic conditions in the channelized cross-sections. The chosen pairs of cross-sections are located between major tributaries (Fig. 5) and carry similar 
Fig. 5 a Location of the Biała River in relation to physiogeographic regions of southern Poland. $b$ Upper and middle parts of the Biała catchment and detailed setting of the studied sites. 1 mountains of intermediate and low height; 2 foothills; 3 intramontane and submontane depressions; 4 boundary of the Biała catchment; 5 flow-gauging stations; 6 study sites ( $\mathrm{S} 1$ to $\mathrm{S} 10)$ and river sections proposed for erodible river corridor. In the figure, sites are indicated in half distance between the unmanaged and the channelized cross-section from a given site

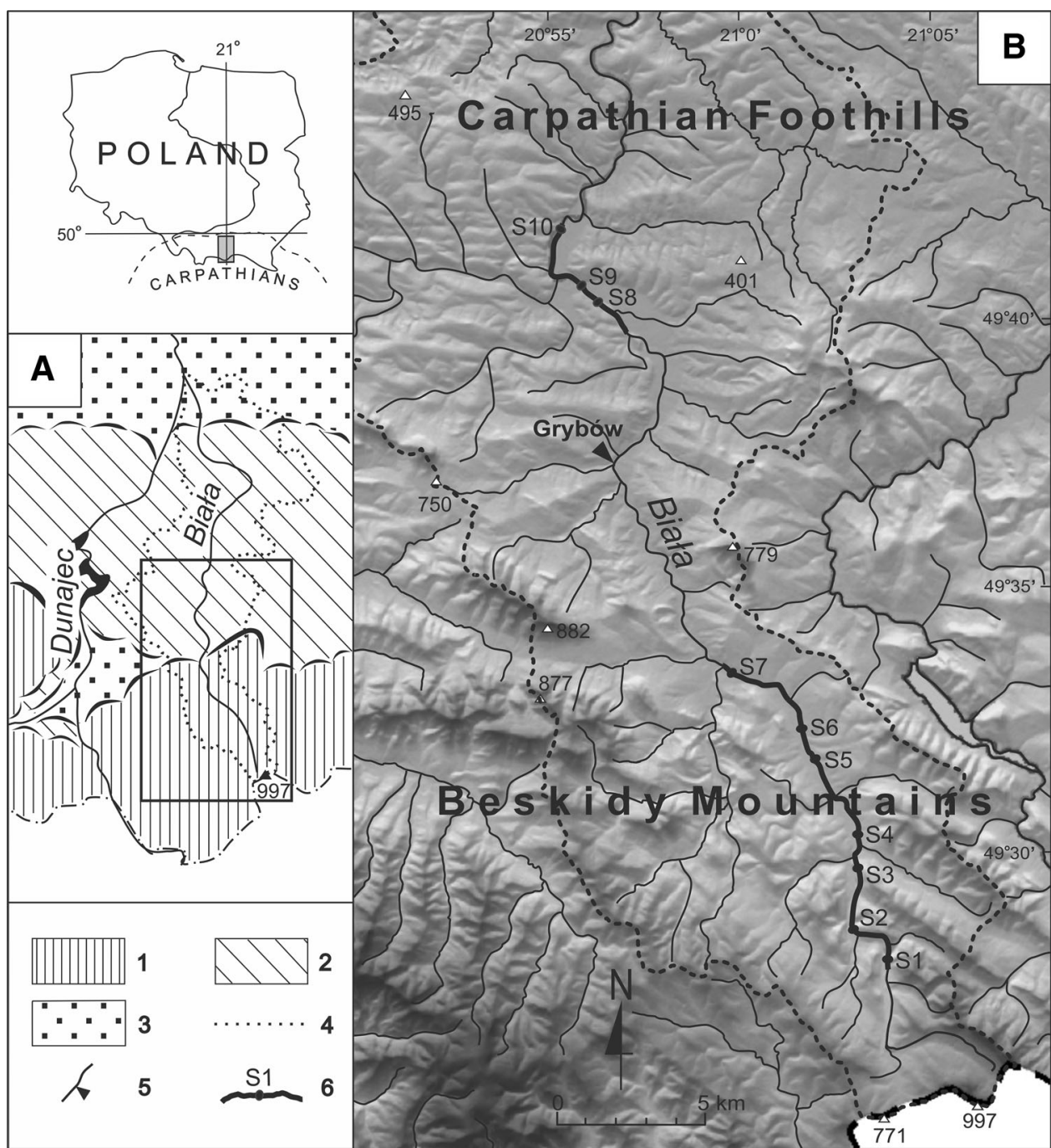

flow. With such location of the cross-sections, the Wilcoxon signed rank test was used to determine statistical significance of the differences in the scores of hydromorphological river quality between the evaluated unmanaged and channelized cross-sections.

\section{Hydromorphological reference conditions}

The most obvious and direct approach to determine reference conditions in the RHQ method is to use characteristics of a river reach that remains in a near-natural state (Wyżga et al. 2012b). However, in the case of the Biała even those reaches which are currently devoid of regulation structures have been affected by earlier (channel training and incision) and recent human activities (uncontrolled gravel extraction or the removal of large wood), and as such they cannot provide information on a reference state of the river. Therefore, reference conditions were determined based on analogue but undisturbed river reaches draining catchments with similar size and environmental conditions (in terms of relief and land use).

Under undisturbed channel conditions, environmental controls on the upper course of the Biała should lead to the formation of a multi-thread channel (cf. Wyżga et al. 2016b). Very few multi-thread river reaches have been preserved in the Polish Carpathians and an unmanaged reach in the middle course of the Czarny Dunajec is the closest analogue of the environmental conditions in the Biała. Using the Czarny Dunajec River as an analogue, reference conditions for the upper Biała can be defined as the occurrence of alluvial, island-braided channel. In its unmanaged reach, the Czarny Dunajec forms a heavily island-braided channel (Wyżga et al. 2010b, 2012b). Because the Biała exhibits significantly higher flow variability, the resultant high lateral mobility of its channel would most likely reduce the development of islands in the river's active zone, typical of the Czarny Dunajec. The latter river typically supports a few low-flow channels, but 
at low to medium water stage only some of them convey a significant proportion of the total flow and have fast water current, whereas the other channels, mostly fed by groundwater, carry low discharges and exhibit slow velocity. Particular channels may differ in depth, width, slope and bed-material grain size (from cobbles to sand or mud). Braids are separated by gravel bars or wooded islands. Riparian zone, floodplain and islands are overgrown with natural, diverse plant communities including herbal communities, tamarisk (Myricaria germanica) and willow shrubs, and mature willow or alder forest. Large wood deposition is common within the river, with a significant proportion of wood deposits represented by whole trees and shrubs (Wyżga and Zawiejska 2010; Wyżga et al. 2015). The river channel has remained vertically stable (no long-term trend in its vertical position has occurred despite the occurrence of short-term fluctuations) at least during the so-called engineering time, i.e. over several decades. For upper sites of the Biała, the analogue reference height of the river banks equals a few tens of centimetres, whereas for sites $6-7$ it is $1.2-1.5 \mathrm{~m}$. Dry palaeochannels and oxbows are present on the floodplain.

Under undisturbed channel conditions, Carpathian rivers draining catchments with similar environmental conditions to the middle Biała catchment form sinuous gravel-bed channels with a distinct tendency to meander (Wyżga 2001), and such reference conditions were indicated for the Biała in the lower section of the planned erodible river corridor (sites 8-10). Such rivers normally carry flow in a single channel; however, occasionally mid-channel bars form within a riffle area leading to the division of flow, and chutes may form inside channel bends that at low to medium water stage are fed by groundwater. Gravel point bars are large. River banks are asymmetric: concave banks are steep and eroding, while convex ones are gentle and aggrading. In vertically stable rivers, a third to a half of the bank profile consists of overbank sands and muds. Convex sides of channel bends are gradually colonized by vegetation, from pioneer herbal communities encroaching on bar tops, to willow shrubs and mature willow and poplar forest. Oxbows and dry, crescent-shaped palaeochannels are common on the floodplain.

\section{Hydromorphological quality of the river at the assessed sites}

Results of the evaluation of particular categories of hydromorphological quality of the Biała and aggregated scores for the paired cross-sections are presented in Fig. 6. The assessment scores ranged from 1.65 (high quality) to 4.13 (poor quality). Scores for the unmanaged cross-sections ranged from 1.65 to 2.59 (Figs. 6, 7a), allowing to associate two of the cross-sections with class 1 of hydromorphological quality and eight cross-sections with class 2 (Fig. 7b). Scores for channelized cross-sections ranged from 3.13 to 4.13 (Figs. 6, 7a), with four such cross-sections falling into class 3 and six into class 4 of hydromorphological quality (Fig. 7b). The average score for the
Fig. 6 Averages of the scores given by five expert evaluators for particular assessment categories and average scores of the hydromorphological river quality in the 10 surveyed pairs of channelized and unmanaged cross-sections of the Biała. Numbers of unmanaged crosssections are shown on white background and those of channelized cross-sections on black background. All scores are shown against hydromorphological quality classes. The vertical scale for each assessed category ranges between 1 (for near-natural conditions) and 5 (for extremely modified conditions)

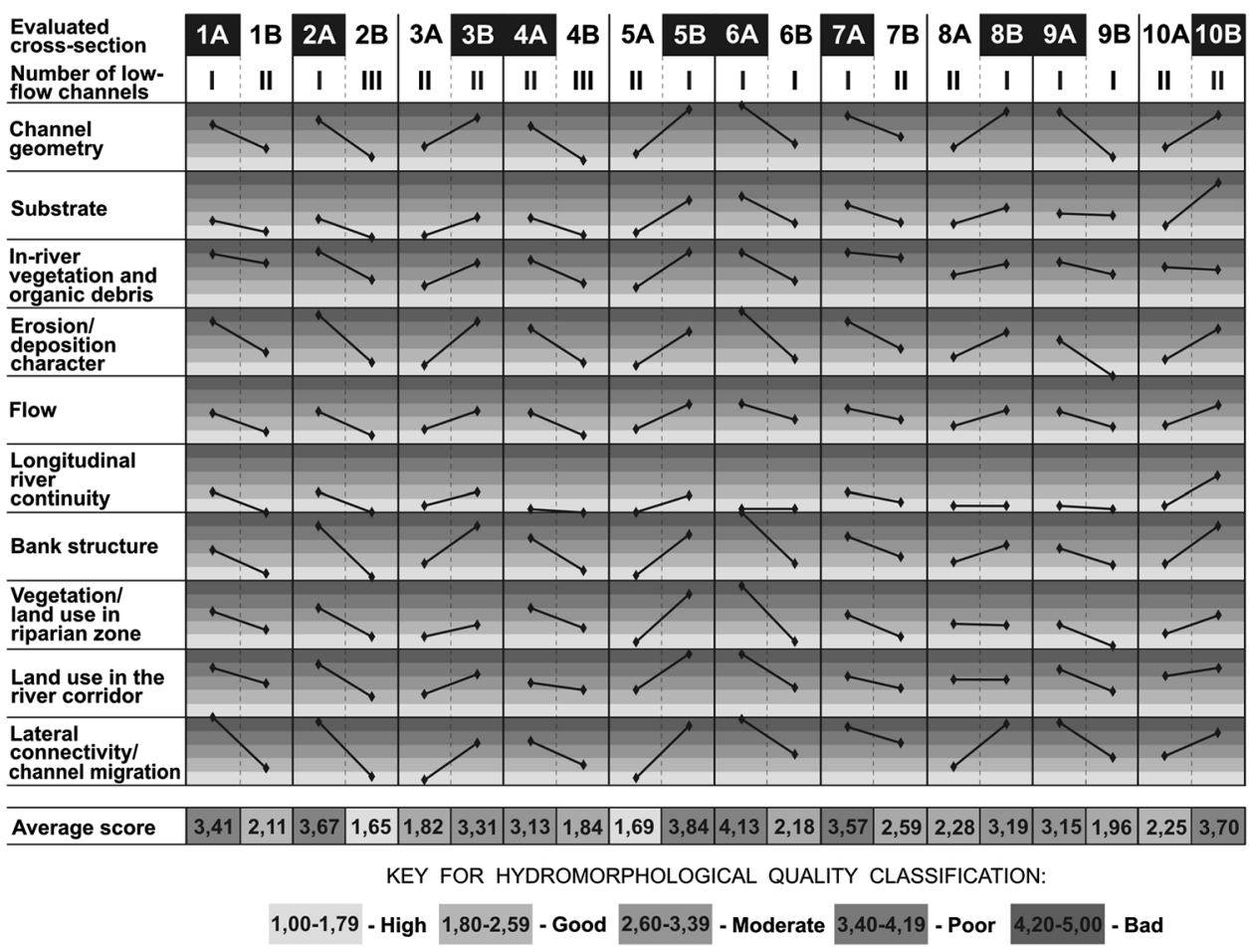


Fig. 7 Average scores (a) and histograms of the classes (b) of hydromorphological river quality in 10 unmanaged (grey diagrams) and 10 channelized (black diagrams) cross-sections of the Biała. The result of a Wilcoxon test for significance of the difference between average scores of hydromorphological river quality in the unmanaged and channelized cross-sections is indicated
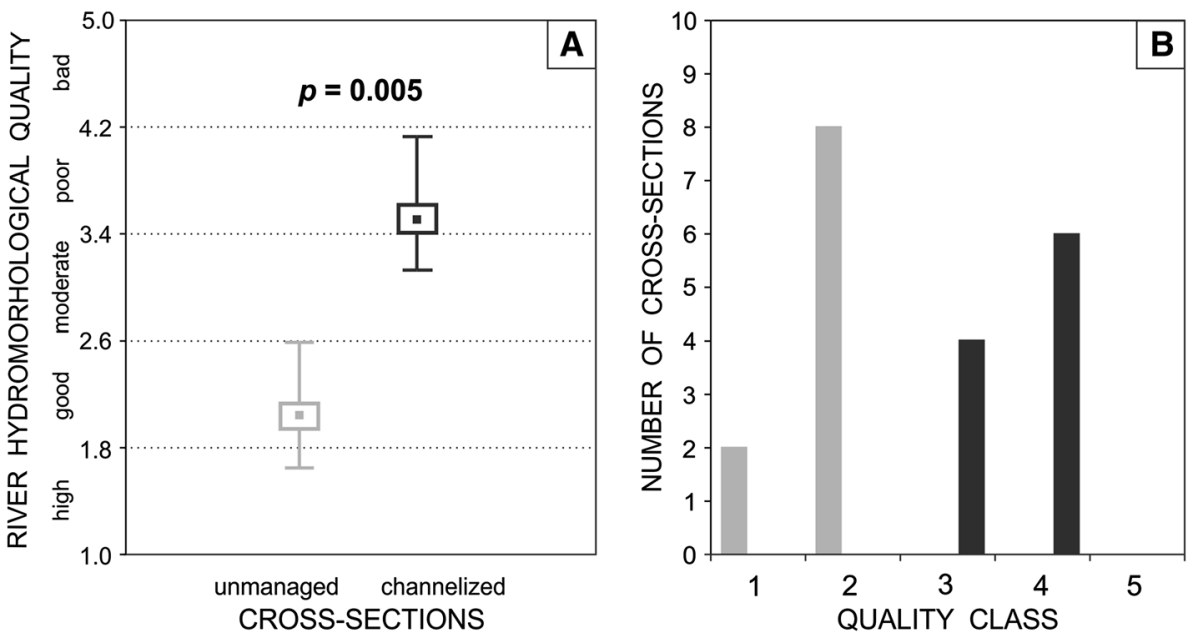

unmanaged cross-sections was 2.04 (class 2) and 3.51 (class 4) for the channelized ones and this difference was statistically significant (Wilcoxon test, $p=0.005$ ) (Fig. 7a).

Differences in hydromorphological quality were also apparent between the mountain and foothill sections of the Biała, with greater range of scores given to the cross-sections located in the mountain river course. Here, unmanaged cross-sections were associated with classes 1 and 2 (two and five cross-sections, respectively), with scores varying between 1.65 and 2.59 . The class 1 cross-sections supported three low-flow channels and had diverse morphology, the presence of erosional and depositional forms and considerable cross-sectional variability of flow velocity and bedmaterial grain size. The cross-sections associated with hydromorphological quality class 2 lacked wooded islands and supported few wood deposits; they were also typified by modified channel geometry, decreased lateral mobility and connectivity resulting from river incision as well as cultivation of the floodplain areas (Fig. 6). Scores for channelized cross-sections ranged from 3.13 to 4.13 , placing two cross-sections in class 3 and five cross-sections in class 4 (Fig. 6). Apart from longitudinal river continuity and bed material in the upstream sites, most components of the river's hydromorphological quality have been modified in these cross-sections. Despite radical changes of flow hydraulics, the overall modification of river flow in channelized crosssections was usually assessed as moderate due to little or no modification to the runoff regime of the Biała (Fig. 6).

Variation in hydromorphological quality of the Biała in its foothill course was less pronounced but also here the two types of cross-sections received distinctly different scores. Unmanaged cross-sections represented class 2, with scores ranging from 1.96 to 2.28 (Fig. 6). A lack of wood deposits in the channel and changes to vegetation in floodplain areas associated with farming lowered the total score (Fig. 6). Scores for the channelized cross-sections ranged between 3.15 and 3.70 , with two of them associated with class 3 and one with class 4 of hydromorphological quality (Fig. 6). With fairly low degree of modification to riparian vegetation and only one of the river banks artificially reinforced, these cross-sections were considered less modified than channelized cross-sections in the upper course of the Biała. A distinctly worse score for the channelized cross-section at site 10 resulted from the disruption of river continuity by a concrete weir located about $100 \mathrm{~m}$ downstream from the cross-section (Fig. 6).

\section{Variation in ten assessment categories of hydromorphological river quality}

Figure 8 compares the range and average scores in particular assessment categories of hydromorphological river quality between unmanaged and channelized cross-sections of the Biała, and indicates statistical significance of the difference between the two types of cross-sections. Channelized crosssections were scored significantly worse in all assessment categories, although the difference between scores for both types of cross-sections varied. Channel geometry was among the categories with the remarkably large difference in naturalness between the two types of river cross-sections: average scores for channelized and unmanaged cross-sections differed by two classes of hydromorphological quality (Fig. 8). Channel geometry in unmanaged cross-sections was considered near-natural or only slightly modified; the latter reflected the effect of river incision on channel geometry. In turn, channelized cross-sections have a radically changed geometry with single-thread, deep and flat-bottomed channel about three times narrower than in unmanaged cross-sections.

Average scores for bed material differed between both types of cross-sections by 1.5 quality classes (Fig. 8). Unmanaged cross-sections at sites 1-5 were typified by 

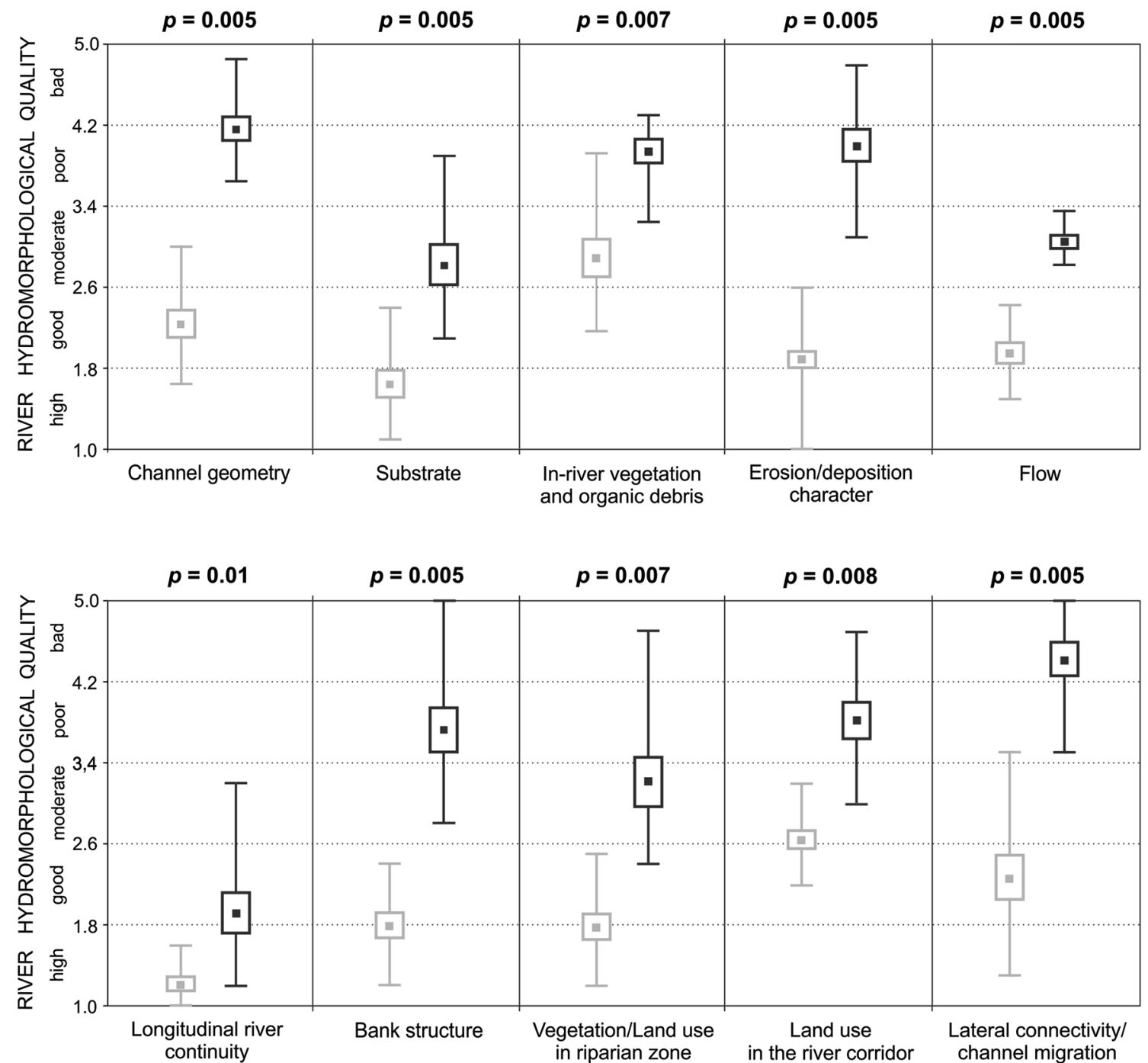

Fig. 8 Range and mean value of the average scores given in particular assessment categories of hydromorphological river quality to 10 surveyed unmanaged cross-sections (grey diagrams) and 10 channelized cross-sections (black diagrams) of the Biała. Range plots show mean value (squares), standard error of the mean (boxes) and

high variability in bed-material grain size (cobbles to mud), that was considered natural, while less spatially variable bed material in the downstream unmanaged cross-sections was regarded as only slightly modified. Gravelly channel bed with well-developed armouring in channelized crosssections was considered moderately modified. The only exception was a concrete channel bed of the channelized cross-section at site 10 that was classified as extremely modified (Fig. 6).

Scores for in-river vegetation and woody debris in channelized and unmanaged cross-sections differed by 1 quality class (Fig. 8). In both cross-section types, aquatic vegetation consisted of algal communities typical of mountain gravelbed rivers. Wooded islands were present in only two out of seven unmanaged cross-sections in the upstream river extreme values (whiskers) of the average scores. For each assessment category, statistical significance of the difference between scores given to both cross-section types, determined by a Wilcoxon test, is indicated; $p$ values $<0.05$ are indicated in bold

section where their occurrence was indicated as typical under undisturbed (reference) conditions. Wood deposits were scarce in unmanaged cross-sections and nearly lacking in channelized ones. All these features were reflected in moderate and poor quality score in this category for the unmanaged and channelized cross-sections.

Average scores for the occurrence of erosional and depositional forms differed between the two types of crosssections by 2.5 quality classes (Fig. 8). The morphological complexity of the river bed was considered natural in a half of unmanaged cross-sections and slightly modified in the other half. With little morphological complexity of the channel bed in channelized cross-sections, the occurrence of erosional and depositional forms was considered highly modified. 
Scores for the river flow in both cross-section types differed by 1.5 quality classes (Fig. 8), which reflected a radical change to flow hydraulics and constraints on the water exchange between river channel and alluvium, caused by bank reinforcements, in channelized crosssections, but also similar runoff regime in closely located channelized and unmanaged cross-sections.

River continuity was given high-quality score in unmanaged cross-sections and good in channelized ones (Fig. 8). The latter score reflected the presence of a 2-mhigh weir downstream of the channelized cross-section at site 10 (Fig. 6) and disturbances to bedload transport caused by a few narrow-span bridges in channelized river reaches.

Average scores given to river banks in the two types of cross-sections differed by 2.5 quality classes (Fig. 8). Only the river banks in unmanaged cross-sections at the upstream-located sites received very good scores. In the unmanaged cross-sections at sites 6-10, the relatively high banks partially cut in bedrock received good score. Markedly worse scores for the banks in channelized crosssections reflected bank reinforcement with gabions or riprap on one or both channel sides.

On average, the scores for vegetation/land use in the riparian zone differed between the two types of crosssections by nearly 2 quality classes (Fig. 8). Riparian vegetation was considered natural in the majority of unmanaged cross-sections and slightly modified in the remaining ones. Bulldozed gravelly surface along the banks in channelized cross-sections was mostly overgrown with ruderal species or grasses. In recently channelized river reaches (cross-sections at sites 5 and 6 ), the riparian area was entirely devoid of vegetation (Fig. 6).

River corridor in the two types of cross-sections obtained scores differing by 1.5 quality classes (Fig. 8). Half of the unmanaged cross-sections had slightly changed floodplain area and in the remaining ones modification was classified as moderate. River corridor adjacent to channelized cross-sections can hardly be inundated and is used either for grazing or housing and infrastructure; the degree of its modification was considered moderate to very high.

Channel mobility and lateral connectivity of the river and floodplain were features with the highest difference in naturalness (2.5 quality classes) between unmanaged and channelized cross-sections (Fig. 8). Bank reinforcement severely limits lateral channel mobility, while the formation of high-capacity channel in the course of river training and channel incision greatly reduces the potential for floodplain inundation and leads to the loss of lateral connectivity of the river ecosystem.

\section{Discussion}

\section{Utility of European standards and assessment methods for river restoration purposes}

Out of the two CEN standards which specified the methodology for hydromorphological assessment of rivers, the earlier EN 14614 standard (CEN 2004) is useful for planning and monitoring of restoration projects. This standard indicates the major features of the channel, river banks, riparian zone and floodplain that are key to the river hydromorphological quality. In contrast, the methodology for the assessment of anthropogenic modification to river hydromorphology proposed in the EN 15843 standard is so simplified that the resultant evaluation can only be useful for creating reports on hydromorphological monitoring of river state required by the Water Framework Directive. The lack of wider utility of the standard was reflected by the voting results during its resolution: out of 30 representatives of the member states, only 21 voted for the acceptance of the standard, while 9 abstained (Boon et al. 2010).

The methods developed for monitoring river hydromorphology, including Polish MHR method (Ilnicki et al. 2010a), aim to provide fast evaluation of many rivers to identify the degree of accomplishment of the environmental objectives of the Water Framework Directive in particular countries. That is why the methods are general and produce results that are not useful for planning and assessment of particular restoration activities. The Polish MHR method was developed to evaluate whole water bodies (rivers) and thus it cannot be used for the assessment of river reaches or particular cross-sections as it was done in the present study with the RHQ method.

In turn, a fundamental flaw of the methods of river habitat assessment is that they do not involve recognition of geomorphological processes influencing the present and the future hydromorphological state of rivers (Rinaldi et al. 2013a, c; Belletti et al. 2015), and this considerably limits their applicability for river restoration purposes. The RHS method belonging to this group involves the assessment of the richness of habitat features beneficial for river biota and includes the richness-based habitat quality in the definition of reference conditions. Consequently, the results of such assessment are incomparable to those based on the degree of deviation from the near-natural/undisturbed conditions. Moreover, the average number of sites evaluated with this method for a given abiotic river type in Poland is low, reflecting a substantially lower total number of evaluated sites (ca. 950; Szoszkiewicz and Gebler 2011) than in the UK (ca. 20,000 sites; Szoszkiewicz et al. 2006) and 26 river types distinguished in the country. This seriously reduces reliability of establishing reference conditions 
(defined by the conditions at the $20 \%$ of highest ranked sites; Raven et al. 2002) and, consequently, also of calibration of hydromorphological conditions at particular sites against type-specific reference conditions.

The criteria for the applicability of a method for planning and monitoring of river restoration, indicated in the earlier part of the paper, are fulfilled by the third of the identified groups of methods, including Polish RHQ method. The set of features analysed in the RHQ method complies with that indicated in the EN 14614 standard and the assessment determines their deviation from reference (undisturbed) state. The method is applicable to any river in Poland (and elsewhere), provided that the assessment is preceded by identification of reference conditions for that river type. Reference conditions are defined taking into account their dynamic character and river adjustment to changing environmental conditions in the catchment (Wyżga et al. 2012b). This is particularly important in the context of land use changes that occurred in southern Poland during the 20th century (e.g. Lach and Wyżga 2002; Kozak et al. 2007), as well as the ongoing and future climate change predicted for the 21st century (e.g. Romanowicz et al. 2016). The method is based on field surveys that allow recognition of the development of all assessed features of the channel, banks and riparian zone as well as floodplain/river corridor. Together with the analysis of cartographic and photographic documentation, this allows the evaluators to recognize adequately the type, location and extent of modifications to river hydromorphology. Considered in the method is the degree of longitudinal, lateral and vertical connectivity of river ecosystem, river adjustment (e.g. bed armouring represents the adjustment of bed substrate resulting from the deficit of bed material in relation to river transport capacity; cf. Wyżga 2012) to environmental changes in the catchment and direct human intervention in the river channel, as well as the impact of the river change on the stability of river banks or the rate of their retreat and the potential for lateral migration of the channel. This allows to analyse the hydromorphological state of assessed river in the context of controlling hydrological and geomorphological processes. As the evaluation is performed by experts from different disciplines of river science, it reflects the opinions expressed from different perspectives and their averaged assessment gives a more objective result than evaluation performed by a specialist from a single discipline of river science (Wyżga et al. 2010b).

\section{Hydromorphological state of the Biała and a measure for its restoration}

Evaluation of the hydromorphological state of the Biała River with RHQ method showed channelized river cross- sections to be in class 4 of hydromorphological quality, and unmanaged cross-sections in class 2 , on average. This points to channel regulation as a major cause of the degradation of hydromorphological state of this river in its upper and middle course. This conclusion was in agreement with the results of a study on benthic macroinvertebrates in the river that identified channelization-induced habitat degradation as the main cause of the deterioration of the river's ecological state (Wyżga et al. 2013). Notably, the difference in scores given to both types of river crosssections was greater at the sites where no channel incision is observed in unmanaged river reaches, but smaller where the Biała is deeply incised in such reaches. A similar pattern of hydromorphological quality was found with the RHQ method for the Czarny Dunajec River, in which channelized cross-sections differed by three quality classes from cross-sections in the unmanaged reach with a multithread, vertically stable channel and by two classes from those in the unmanaged reach with a single-thread, deeply incised channel (Wyżga et al. 2009, 2010b). Also in this river, the spectacular disparity in hydromorphological quality scores between different types of cross-sections was reflected in marked differences in the richness of riverine communities: fish (Wyżga et al. 2009) and benthic macroinvertebrates (Wyżga et al. 2012a).

Establishing the erodible corridor in which the river is allowed to develop its channel freely will promote improvement of the hydromorphological conditions degraded as a consequence of the river channelization and the simultaneous adjustment of fluvial forms and processes to ongoing environmental changes in the catchment. This method of restoration of the Biała will be also cost-effective in the unmanaged river reaches in which most of the riparian areas is a state property and the potential impacts of free channel migration on private lands as well as settlements and infrastructure on the valley floor are minimal (Wyżga et al. 2014). A recent occurrence of a large flood on the Biała initiated self-recovery of the river in the unmanaged reaches within the erodible corridor. The flood increased the river width in these reaches by half, on average, although the degree of river widening was smaller in the deeply incised river sections and greater in its less incised sections (Hajdukiewicz et al. 2016). After the flood, unmanaged reaches of the Biała are typified by markedly smaller values of unit stream power and bed shear stress than channelized reaches (Czech et al. 2016) and this, together with the delivery of coarse material from eroded channel banks and tributaries, will likely promote the cessation and reversal of the tendency to channel incision.

The largest differences (by two classes) in hydromorphological quality between channelized and unmanaged cross-sections were associated with channel geometry, the presence of erosional and depositional channel forms, bank 
structure, channel mobility and lateral connectivity of the river and its floodplain. This enables identification of those features that will likely improve the most with the removal of bank protection and allowing free channel migration. The smallest difference in hydromorphological quality was found with regard to longitudinal river continuity which reflects the lack of transversal engineering structures (with only one exception) in the studied sections of the Biała.

The evaluation of the Biała also showed that despite significantly better hydromorphological quality of the river in the unmanaged cross-sections, in most of them and in most assessed categories this quality is still below the high category, typical of rivers with undisturbed fluvial processes. However, considering the long-term human pressure on the river over the past century, the results of the evaluation are hardly surprising. Unrestricted functioning of the river within the delimited corridor may significantly improve several elements of its hydromorphological quality, also those most modified such as in-river vegetation and woody debris or floodplain land use. A marked improvement of some hydromorphological features, such as channel planform or the presence of erosional and depositional channel forms, may be attained over several years as a result of the passage of a few flood waves. However, a few tens of years will be necessary for the incised river to form new, low-lying floodplains and for these areas to be vegetated by spontaneous succession of riparian plant communities which will next supply wood debris to the river. A direct effect of the establishment of the erodible river corridor is the onset of free channel mobility, but the expected improvement of the river's hydromorphological state may be achieved after a period markedly longer than the duration of the restoration project itself.

\section{Conclusions}

Assessment of river hydromorphological state for river restoration purposes should not only determine its current quality but also diagnose reasons for its degradation and pinpoint features that need improvement so that the planned restoration measures will be accurate and lead to an increase in river integrity. Out of the three methods of hydromorphological assessment used in Poland, only the RHQ method fulfills all the criteria for methods useful for planning and monitoring of river restoration projects. The assessment of the Biała with the RHQ method indicated two unmanaged cross-sections to fall in class 1 of hydromorphological quality and eight such cross-sections in class 2. In turn, four channelized cross-sections were classified to represent class 3 and six class 4 . With the average scores of 2.04 (class 2) and 3.51 (class 4), the two types of river cross-sections significantly differed in hydromorphological quality. Although unmanaged and channelized cross-sections differed in each assessment category of hydromorphological quality, channel geometry, the presence of erosional and depositional channel forms, bank structure, channel mobility and lateral connectivity of the river and its floodplain were identified to be most severely modified as a result of the river channelization. These river features are thus likely to be improved the most with allowing free channel migration within the erodible river corridor. Differences in hydromorphological quality between the two types of cross-sections were somewhat less pronounced at the sites where the river is deeply incised in unmanaged and channelized reaches.

Acknowledgements This study has been supported by the statutory funds of the Institute of Nature Conservation, Polish Academy of Sciences. The final manuscript benefited from the efforts of three anonymous reviewers.

Open Access This article is distributed under the terms of the Creative Commons Attribution 4.0 International License (http://crea tivecommons.org/licenses/by/4.0/), which permits unrestricted use, distribution, and reproduction in any medium, provided you give appropriate credit to the original author(s) and the source, provide a link to the Creative Commons license, and indicate if changes were made.

\section{References}

Belletti B, Rinaldi M, Buijse AD, Gurnell AM, Mosselman E (2015) A review of assessment methods for river hydromorphology. Environ Earth Sci 73:2078-2100. doi:10.1007/s12665-0143558-1

Boon PJ, Holmes NTH, Raven PJ (2010) Developing standard approaches for recording and assessing river hydromorphology: the role of the European Committee for Standardization (CEN). Aquat Conserv Mar Freshw Ecosyst 20:55-61. doi:10.1002/aqc.1097

Brierley GJ, Fryirs K (2005) Geomorphology and river management: applications of the River Styles Framework. Blackwell, Oxford, p 416

Brunke M, Gonser T (1997) The ecological significance of exchange processes between rivers and groundwater. Freshw Biol 37:1-33. doi:10.1046/j.1365-2427.1997.00143.x

CEN (2004) Water quality-guidance standard for assessing the hydromorphological features of rivers, EN 14614. CEN, Brussels, p 21

CEN (2010) Water quality-guidance standard on determining the degree of modification of river hydromorphology, EN 15843. CEN, Brussels, p 24

Czech W, Radecki-Pawlik A, Wyżga B, Hajdukiewicz H (2016) Modelling the flooding capacity of a Polish Carpathian river: a comparison of constrained and free channel conditions. Geomorphology 272:32-42. doi:10.1016/j.geomorph.2015.09.025

Dufour S, Piégay H (2009) From the myth of a lost paradise to targeted river restoration: forget natural references and focus on human benefits. River Res Appl 25:568-581. doi:10.1002/rra. 1239

Elosegi A, Sabater S (2013) Effects of hydromorphological impacts on river ecosystem functioning: a review and suggestions for 
assessing ecological impacts. Hydrobiologia 712:129-143. doi:10.1007/s10750-012-1226-6

Elosegi A, Díez J, Mutz M (2010) Effects of hydromorphological integrity on biodiversity and functioning of river ecosystems. Hydrobiologia 657:199-215. doi:10.1007/s10750-009-0083-4

EPA (2001) Parameters of water quality. Interpretation and standards. Environmental Protection Agency, Wexford, p 132

European Commission (2000) Directive 2000/60/EC of the European Parliament and of the Council of 23 October 2000 establishing a framework for Community action in the field of water policy. Off J Eur Commun L 324(43):1-72

Habersack H, Piégay H (2008) River restoration in the Alps and their surroundings: past experience and future challenges. In: Habersack H, Piégay H, Rinaldi M (eds) Gravel-bed rivers VI: from process understanding to river restoration. Developments in earth surface processes 11. Elsevier, Amsterdam, pp 703-737. doi:10.1016/S0928-2025(07)11161-5

Hajdukiewicz H, Wyżga B, Mikuś P, Zawiejska J, Radecki-Pawlik A (2016) Impact of a large flood on mountain river habitats, channel morphology and valley infrastructure. Geomorphology 272:55-67. doi:10.1016/j.geomorph.2015.09.003

Ilnicki P, Górecki K, Grzybowski M, Krzemińska A, Lewandowski P, Sojka M (2010a) Principles of hydromorphological surveys of Polish rivers. J Water Land Develop 14:3-13. doi:10.2478/ v10025-011-0001-9

Ilnicki P, Górecki K, Grzybowski M, Krzemińska A, Lewandowski P, Sojka M (2010b) Ecological quality classes of river hydromorphology. J Water Land Develop 14:15-27. doi:10.2478/v10025011-0002-8

Kaczka RJ, Wyżga B, Zawiejska J (2008) Tree ring study of the island formation and riparian forest along a gravel-bed river in the Polish Carpathians. In: Elferts D, Brumelis G, Gärtner H, Helle G, Schleser G (eds) Tree rings in archaeology, climatology and ecology 6, Proceedings of the Dendrosymposium 2007, 3-6 May 2007, Riga, Latvia. Association for Tree Ring Research, Potsdam, 106-110

Kondolf GM, Piégay H, Landon N (2002) Channel response to increased and decreased bedload supply from land use change: contrasts between two catchments. Geomorphology 45:35-51. doi:10.1016/S0169-555X(01)00188-X

Kondolf GM, Boulton AJ, O'Daniel S, Poole GC, Rahel FJ, Stanley EH, Wohl E, Bång A, Carlstrom J, Cristoni C, Huber H, Koljonen S, Louhi P, Nakamura K (2006) Process-based ecological river restoration: visualizing three-dimensional connectivity and dynamic vectors to recover lost linkages. Ecol Soc 11:5. doi:10.5751/ES-01747-110205

Kozak J, Estreguil C, Troll M (2007) Forest cover changes in the northern Carpathians in the 20th century: a slow transition. J Land Use Sci 2:127-146. doi:10.1080/ 17474230701218244

Kujanová K, Matoušková M, Kliment Z (2016) Hydromorphological parameters of natural channel behavior in conditions of the Hercynian System and the flysch belt of the Western Carpathians on the territory of the Czech Republic. Geomorphology 258:69-81. doi:10.1016/j.geomorph.2016.01.016

Kundzewicz ZW, Stoffel M, Kaczka RJ, Wyżga B, Niedźwiedź T, Pińskwar I, Ruiz-Villanueva V, Łupikasza E, Czajka B, Ballesteros-Canovas JA, Małarzewski Ł, Choryński A, Janecka K, Mikuś P (2014) Floods at the northern foothills of the Tatra Mountains-a Polish-Swiss research project. Acta Geophys 62:620-641. doi:10.2478/s11600-013-0192-3

Lach J, Wyżga B (2002) Channel incision and flow increase of the upper Wisłoka River, southern Poland, subsequent to the reafforestation of its catchment. Earth Surf Process Landforms 27:445-462. doi:10.1002/esp.329
Langhammer J (2007) HEM Hydroekologicky monitoring. Metodika pro monitoring hydromorfologickych ukazatelů ekologicke kvality vodnich toků. PřF UK, Praha, p 66

LAWA (2000) Gewässerstrukturgütebewertung in der Bundesrepublik Deutschland, Verfahren für kleine und mittelgroße Fließgewässer. Landerarbeitsgemeinschaft Wasser, Schwerin

Lewandowski P (2012) Polish investigations on river hydromorphology. Polish J Environ Stud 21:957-965

Meybeck M (2003) Global analysis of river systems: from Earth system controls to Anthropocene syndromes. Phil Trans R Soc Lond B 1379:1-21. doi:10.1098/rstb.2003.1379

Mikuś P, Wyżga B, Kaczka RJ, Walusiak E, Zawiejska J (2013) Islands in a European mountain river: linkages with large wood deposition, flood flows and plant diversity. Geomorphology 202:115-127. doi:10.1016/j.geomorph.2012.09.016

Montgomery DR, Buffington JM (1997) Channel-reach morphology in mountain drainage basins. Geol Soc Am Bull 109:596-611

Muhar S, Jungwirth M (1998) Habitat integrity of running watersassessment criteria and their biological relevance. Hydrobiologia 386:195-202

Ollero A, Ibisate A, Gonsalo LE, Acín V, Ballarín D, Díaz E, Domenech S, Gimeno M, Granado D, Horacio J, Mora D, Sánchez M (2011) The IHG index for hydromorphological quality assessment of rivers and streams: updated version. Limnetica 30:255-261

Raven PJ, Fox P, Everard M, Holmes NTH, Dawson FH (1997) River habitat survey: a new system for classifying rivers according to their habitat quality. In: Boon PJ, Howell DL (eds) Freshwater quality: defining the indefinable? The Stationery Office, Edinburgh, pp 215-234

Raven PJ, Holmes NTH, Charrier P, Dawson FH, Naura M, Boon PJ (2002) Towards a harmonized approach for hydromorphological assessment of rivers in Europe: a qualitative comparison of three survey methods. Aquat Conserv Mar Freshw Ecosyst 12:405-424. doi:10.1002/aqc.536

Rinaldi M, Wyżga B, Surian N (2005) Sediment mining in alluvial channels: physical effects and management perspectives. River Res Appl 21:805-828. doi:10.1002/rra.884

Rinaldi M, Belletti B, Van de Bund W, Bertoldi W, Gurnell A, Buijse T, Mosselman E (2013a) Review on hydromorphological methods. Report of FP7 REFORM Project, p 202

Rinaldi M, Surian N, Comiti F, Bussettini M (2013b) A method for the assessment and analysis of the hydromorphological condition of Italian streams: the morphological quality index (MQI). Geomorphology 180:96-108. doi:10.1016/j.geomorph.2012.09. 009

Rinaldi M, Wyżga B, Dufour S, Bertoldi W, Gurnell A (2013c) River processes and implications for fluvial ecogeomorphology: a European perspective. In: Shroder J, Butler DR, Hupp CR (eds) Treatise on Geomorphology. Vol. 12. Ecogeomorphology. Academic Press, San Diego, 37-52, doi:10.1016/B978-0-12374739-6.00321-3

Romanowicz RJ, Bogdanowicz E, Debele SE, Doroszkiewicz J, Hisdal H, Lawrence D, Meresa HK, Napiórkowski JJ, Osuch M, Strupczewski WG, Wilson D, Wong WK (2016) Climate change impact on hydrological extremes: preliminary results from the Polish-Norwegian project. Acta Geophys 64:477-509. doi:10. 1515/acgeo-2016-0009

Scheifhacken N, Haase U, Gram-Radu L, Kozovyi R, Berendonk TU (2012) How to assess hydromorphology? A comparison of Ukrainian and German approaches. Environ Earth Sci 65:1483-1499. doi:10.1007/s12665-011-1218-2

Surian N, Rinaldi M (2004) Channel adjustments in response to human alterations of sediment fluxes: examples from Italian rivers. In: Golosov V, Belyaev V, Walling DE (eds) Sediment 
transfer through the fluvial system. Intern Ass Hydrol Sci Publ 288, 276-282

Szoszkiewicz K, Gebler D (2011) Ocena warunków hydromorfologicznych rzek w Polsce metodą River Habitat Survey (Assessment of hydromorphological conditions in Polish rivers based on the River Habitat Survey). Ochr Środ Zas Natur 47, 70-81 (in Polish, with English summary)

Szoszkiewicz K, Buffagni A, Davy-Bowker J, Lesny J, Chojnicki BH, Zbierska J, Staniszewski R, Zgola T (2006) Occurrence and variability of River Habitat Survey features across Europe and the consequences for data collection and evaluation. Hydrobiologia 566:267-280. doi:10.1007/s10750-006-0090-7

Szoszkiewicz K, Zgoła T, Jusik S, Hryc-Jusik B, Raven P, Dawson FH (2007) Ocena hydromorfologiczna wód płynących. Podręcznik do badań terenowych według metody River Habitat Survey. Bogucki Wydawnictwo Naukowe, Poznań, p 163

Tockner K, Ward JV, Arscott DB, Edwards PJ, Kollmann J, Gurnell AM, Petts GE, Maiolini B (2003) The Tagliamento River: a model ecosystem of European importance. Aquat Sci 65:239-253. doi:10.1007/s00027-003-0699-9

Vaughan IP, Diamond M, Gurnell AM, Hall KA, Jenkins A, Milner NJ, Naylor LA, Sear DA, Woodward G, Ormerod S (2009) Integrating ecology with hydromorphology: a priority for river science and management. Aquat Conserv Mar Freshw Ecosyst 19:113-125. doi:10.1002/aqc.895

Wood PJ, Armitage PD (1997) Biological effects of fine sediment in the lotic environment. Environ Manage 21:203-217

Wyżga B (1997) Methods for studying the response of flood flows to channel change. J Hydrol 198:271-288. doi:10.1016/S00221694(96)03289-1

Wyżga B (2001) A geomorphologist's criticism of the engineering approach to channelization of gravel-bed rivers: case study of the Raba River, Polish Carpathians. Environ Manage 28:341-358. doi: $10.1007 / \mathrm{s} 002670010228$

Wyżga B (2008) A review on channel incision in the Polish Carpathian rivers during the 20th century. In: Habersack $H$, Piegay H, Rinaldi M (eds) Gravel-bed rivers VI: from process understanding to river restoration. Developments in earth surface processes 11. Elsevier, Amsterdam, pp 525-555. doi:10.1016/ S0928-2025(07)11142-1

Wyżga B (2012) Cechy teksturalne żwirowych osadów korytowych jako odzwierciedlenie dynamiki przepływu wody i transportu rumowiska $\mathrm{w}$ ciekach $\mathrm{z}$ różnych stref klimatycznych (Textural patterns of river gravels as a reflection of water and sediment dynamics in watercourses from various climatic zones). In: Łajczak A et al (eds) Antropopresja w wybranych strefach morfoklimatycznych-zapis zmian w rzeźbie i osadach. Uniwersytet Śląski, Sosnowiec, pp 461-469

Wyżga B, Zawiejska J (2010) Large wood storage in channelized and unmanaged sections of the Czarny Dunajec River, Polish
Carpathians: Implications for the restoration of mountain rivers. Folia Geogr Ser Geogr Phys 41:5-34

Wyżga B, Amirowicz A, Radecki-Pawlik A, Zawiejska J (2009) Hydromorphological conditions, potential fish habitats, and the fish community in a mountain river subjected to variable human impacts, the Czarny Dunajec, Polish Carpathians. River Res Appl 25:517-536. doi:10.1002/rra.1237

Wyżga B, Hajdukiewicz H, Radecki-Pawlik A, Zawiejska J (2010a) Eksploatacja osadów z koryt rzek górskich-skutki środowiskowe i procedury oceny (Exploitation of sediments from mountain river beds-environmental impact and evaluation procedures). Gosp Wodna 6:243-249 (in Polish, with English summary)

Wyżga B, Zawiejska J, Radecki-Pawlik A, Amirowicz A (2010b) A method for the assessment of hydromorphological river quality and its application to the Czarny Dunajec, Polish Carpathians. In: Radecki-Pawlik A, Hernik J (eds) Cultural Landscapes of River Valleys. Agricultural University in Kraków, Kraków, pp 145-164

Wyżga B, Oglęcki P, Radecki-Pawlik A, Skalski T, Zawiejska J (2012a) Hydromorphological complexity as a driver of the diversity of benthic invertebrate communities in the Czarny Dunajec River, Polish Carpathians. Hydrobiologia 696:29-46. doi:10.1007/s10750-012-1180-3

Wyżga B, Zawiejska J, Radecki-Pawlik A, Hajdukiewicz H (2012b) Environmental change, hydromorphological reference conditions and the restoration of Polish Carpathian rivers. Earth Surf Process Landforms 37:1213-1226. doi:10.1002/esp.3273

Wyżga B, Oglęcki P, Hajdukiewicz H, Zawiejska J, Radecki-Pawlik A, Skalski T, Mikuś P (2013) Interpretation of the invertebratebased BMWP-PL index in a gravel-bed river: insight from the Polish Carpathians. Hydrobiologia 712:71-88. doi:10.1007/ s10750-012-1280-0

Wyżga B, Amirowicz A, Oglęcki P, Hajdukiewicz H, Radecki-Pawlik A, Zawiejska J, Mikuś P (2014) Response of fish and benthic invertebrate communities to constrained channel conditions in a mountain river: case study of the Biała, Polish Carpathians. Limnologica 46:58-69. doi:10.1016/j.limno.2013.12.002

Wyżga B, Zawiejska J, Mikuś P, Kaczka RJ (2015) Contrasting patterns of wood storage in mountain watercourses narrower and wider than the height of riparian trees. Geomorphology 228:275-285. doi:10.1016/j.geomorph.2014.09.014

Wyżga B, Kundzewicz ZW, Ruiz-Villanueva V, Zawiejska J (2016a) Flood generation mechanisms and changes in principal drivers. In: Kundzewicz ZW, Stoffel M, Niedźwiedź T, Wyżga B (eds) Flood risk in the upper vistula basin. Springer, Cham, pp 55-75. doi:10.1007/978-3-319-41923-7_4

Wyżga B, Zawiejska J, Hajdukiewicz H (2016b) Multi-thread rivers in the Polish Carpathians: occurrence, decline and possibilities of restoration. Quatern Intern 415:344-356. doi:10.1016/j.quaint. 2015.05.015 